\title{
A MORPHOMETRIC STUDY OF THE INTESTINAL MUCOSA OF RATS SUBMITTED TO OMENTOENTEROPEXY
}

\author{
Pedro Muñoz FERNANDEZ, Fabíola POLLACHI, Rafael Alves CORDEIRO, \\ Ana Maria A. A. MADER and Wilson Roberto CATAPANI
}

\begin{abstract}
Context - The omentoenteropexy technique was developed as an alternative method for intestinal neovascularization, due to the angiogenic properties of factors from the omentum. Objectives - This study investigated changes in intestinal villi heights and crypts depths due to surgical techniques: seromiotomy with and without omentoenteropexy. Method - Thirty rats were operated on, after being divided into three groups, namely GI, GII and GIII with 10 rats each. In the GI rats were submitted to omentoenteropexy; rats in GII were submitted only to a seromiotomy, and in the GIII only laparotomy. Sixty days after the first surgery, the animals were sacrificed and a segment of intestine was removed for histology using Masson's trichrome technique and morphometric study of intestinal mucosa. Results - The histological findings showed that seromiotomy with or without omentoenteropexy increased the length of intestinal villi when compared with GIII (only laparotomy) (analysis of variance: $P=0.0068$; GI $38.88 \pm 4.17$; GII 39.41 \pm 6.33 ; GIII $31.85 \pm 5.56$; GI $=$ GII $P>0.05$; GII $>$ GIII $P<0.05$; GI $>$ GIII $P<0.001)$. Conclusion - No differences were demonstrated in relation to crypt depths between the groups $(P=0.60)$. Ongoing studies are being set forth by our group to add more data on the role of omentopexy as a tool to promote neovascularization and intestinal mucosal growth.
\end{abstract}

HEADINGS - Omentum, surgery. Intestinal mucosa. Rats.

\section{INTRODUCTION}

The malabsorption state due to reduced absorptive surface of the small intestine is a clinical condition named the short bowel syndrome. Its causes are varied; it can often be due to inflammatory bowel disease and ischemic conditions in adults, and necrotizing enteritis in children. Surgical treatment has been seeking techniques either to stimulate the growth of the mucosa, slow down the intestinal transit or to increase the absorptive surface of the intestine through the intestinal lengthening.

One of these techniques is neovascularization by omentoenteropexy, which was proposed as an alternative experimental technique of neovascularization by Shoshany et al. ${ }^{(11)}$, in 1994. These authors suggested the use of an alternative organ, the greater omentum, for neovascularization of an isolated segment of intestine, raising the possible limitations of the former models that had been proposed, which used abdominal muscles or liver for that purpose ${ }^{(11)}$.

Rocha et al. ${ }^{(8)}$ published the first omentoenteropexy study in a non-isolated jejunal segment, which consisted of an omentoenteropexy 6 centimeters long, held in a jejunal segment 20 centimeters distal to the duodenum - jejunal angle. Seven weeks after the procedure, this segment had its mesenteric vasculature ligated, and a section of bowel proximal and distal to the neovascularized segment was performed, followed by anastomosis to restore the bowel transit. No mechanical or functional obstruction ocurred with this procedure.

In 2002, Rocha et al. ${ }^{(7)}$ studied histologically non isolated, neovascularized jejunal segments and observed a reduction in the number of ganglionic cells, and dilatation of the neovascularized segment compared to control groups. Rocha et al. ${ }^{(9)}$, in the following year, continued with the histologic and immunohistochemical study of the intestinal neovascularized segment, demonstrating the occurrence of thickening of the muscular layer and increase in the size of the villi and crypts, in addition to the changes described in the previous study.

It was suggested that the omentum has the ability to induce angiogenesis or mediate it through certain lipidic factors ${ }^{(1,2)}$. Some studies have evaluated the angiogenic potential of these factors from the development of experimental models in rabbit corneas, in order to quantify the neovascularization ${ }^{(1)}$. The lipid material obtained from the omentum contains a potent angiogenic factor extracted by a mixture of chloroform and metanol ${ }^{(1,2)}$. It is possible to create an isolated segment of bowel that is completely free of its mesentery, still with preserved viability and function ${ }^{(3,11)}$. 
The aim of this study was to evaluate changes in intestinal villus height and crypt depth of rats submitted to omentoenteropexy, when compared to controls.

\section{METHODS}

Sample: a total of 38 male young adults Wistar rats, weighing between $134 \mathrm{~g}$ and $234 \mathrm{~g}$ comprised the initial sample. Of these, 30 rats were divided randomly into three groups of 10 rats each and observed for 60 days postoperatively.

Preoperative period and anesthesia: the animals were fasted for 4 hours. Anesthesia was performed with xylazine $1.3 \mathrm{mg} / \mathrm{kg}$ IM and ketamine $25 \mathrm{mg} / \mathrm{kg}$ IM for each rat.

Operative procedure: asepsis with $0.5 \%$ chlorhexidine alcoholic solution, placement of fenestrated sterile cloth. Median laparotomy $5 \mathrm{~cm}$ in length, $2 \mathrm{~cm}$ below the xiphoid process for all groups.

Then, for each group the following procedures were performed:

GI: exposition of the bowel and performing of an antimesenteric seromiotomy, $6 \mathrm{~cm}$ in length, located $20 \mathrm{~cm}$ from the duodeno jejunal transition. The proximal portion of the seromiotomy was marked with 6-0 polypropylene suture thread with cardiovascular RB-1 needle, and $6 \mathrm{~cm}$ distal to this site a second point was marked with the same thread, at the end of seromiotomy. The counter-mesenteric serosal edge was sectioned $6 \mathrm{~cm}$ in length using a Gillette ${ }^{\circledR}$ blade, and the omentoenteropexy was performed with four separated stitches using the same polypropylene 6-0 thread.

GII: exposure of intestinal loops with the same procedure described above, but without the omentoenteropexy.

GIII: exposure of intestinal loops for 10 minutes and return them to the abdominal cavity.

In all groups the closure of the abdominal cavity was done by layers: peritoneum with 6-0 polypropylene continuous suture, aponeurosis with 5-0 polypropylene sutures and skin with separated intradermal stitches with poligalactilin 5-0.

Postoperative period: the rats were separated into individual cages and fed in the immediate postoperative period as soon they recovered from anesthesia. Analgesia was achieved orally in a single dose of tramadol hydrochloride, $5 \mathrm{mg} / \mathrm{kg} /$ day.

Euthanasia: euthanasia of animals was performed in a $\mathrm{CO}_{2}$ chamber.

Morphometric analysis: the histopathologic staining was performed by Masson's trichrome technique. Villus height and depth of crypts were measured using an appropriate reticle placed in the eyepiece of a conventional microscope. Villi heights and crypt depths were expressed in units of the reticle. About 8-9 villi and crypts were measured for each rat.

\section{Statistics}

The mean villus height and crypt depth were obtained for each rat. Therefore, each group of 10 rats was represented by 10 individual means of each parameter.

For comparisons of parameters between the three groups, we used analysis of variance (with Tukey post-test if the difference was significant).
Ethical aspects: the present study was approved by the Animal Research Ethics Comitee of FMABC, Santo André, SP, Brazil.

\section{RESULTS}

Histological findings showed that both groups GI and GII had comparable mean villi heights, being both significantly greater than group GIII (Table 1).

Crypt depths showed no significant differences among the three groups (Table 2).

TABLE 1. Villus height (mean and standard deviations), measured in reticle units among Groups I, II and III

\begin{tabular}{lccc}
\hline & GI & GII & GIII \\
\hline Mean & 38.88 & 39.41 & 31.85 \\
SD & \pm 4.17 & \pm 6.33 & \pm 5.56 \\
\hline
\end{tabular}

ANOVA with Tukey test $P=0.0068$

$\mathrm{GI}=\mathrm{GII}(P>0.05)$

GII $>$ GIII $(P<0.05)$

GI $>$ GIII $(P<0.001)$

$\mathrm{SD}=$ Standard deviation

TABLE 2. Crypt depths, (mean and standard deviations), measured in reticle units among Groups I, II and III

\begin{tabular}{lccc}
\hline & GI & GII & GIII \\
\hline Mean & 13.57 & 13.71 & 14.5 \\
SD & \pm 1.4 & \pm 2.73 & \pm 2.35 \\
\hline
\end{tabular}

ANOVA $P=0.60$

$\mathrm{SD}=$ Standard deviation

\section{DISCUSSION}

The study aimed to evaluate morphometric changes associated with the enteroomentopexy technique. Two control groups were used, one of them undergone a sham laparotomy, and the other only a seromiotomy, without omentopexy.

Several time intervals between the two laparotomies were found in the literature, ranging from 4 to 8 weeks ${ }^{(5,6,11,12)}$. We chose a period of 8 weeks in order to have enough time for well established histological changes.

The use of the greater omentum as a provider of intestinal neovascularization has many advantages. The procedure is simple and can be used without major risks for the animal. It has been documented that the omentum, as well as other fatty tissues, has intense angiogenic activity $(1,3,4,10)$. In total, 38 rats were used in this experiment. Of these, 30 rats comprised the final sample. Concerning the remaining eight rats, two died during anesthetics induction and two postoperatively. The remaining four rats were excluded from the experiment by accidental opening of the mucosal layer during surgery. Besides the accidental opening of the intestinal loop, one rat had a cecum puncture, which was repaired by suture with 6-0 polypropylene and antibiotic prophylaxis with norfloxacin. Among the intraoperative findings at the second laparotomy, in GII adhesions with the liver edge were found in three rats.

The Masson trichrome staining and transversal sections of the gut allowed good overview of the histological sections, 
the muscular layer and the mucosal layer with its villi and crypts were easily defined and measured.

As for the villus heights, they were similar in the groups where only a seromiotomy was performed (GII), or a seromiotomy plus omentopexy (GI). Indeed, both groups had a significantly greater villus height when compared to the sham laparotomy control group (GIII), where no section in the gut was done. It is possible that this result could be due to an increase in blood flow to the mucosa resulting from the procedures performed on the gut in GI and GII. However, it is noticeable the similarity in villus heights between these two groups (Table 2). Thus, the role of the omentopexy in this process remain to be established, since seromiotomy alone or seromiotomy plus omentopexy had similar an outcome as concerning villus heights. In regard to crypt depths, there were no significant differences between the three groups. As a whole, enteroomentopexy did not appear to cause a different effect on these parameters than a single seromiotomy.

However, the relationship between villi and crypts is a dynamic process, and our study reflected the data obtained at a given moment ( 8 weeks post first operation). A sequential study of the mucosal kinetics would be more suitable to better establish this relationship. Ongoing studies are being set forth by our group to add more data on the role of omentopexy as a tool to promote neovascularization and mucosal growth.

Fernandez PM, Pollachi F, Cordeiro RA, Mader AMAA, Catapani RC. Estudo morfométrico da mucosa intestinal de ratos submetidos a omentoenteropexia. Arq Gastroenterol. 2011;48(4):283-5.

RESUMO - Contexto - A omentoenteropexia foi desenvolvida como técnica alternativa para a neovascularização intestinal, devido às propriedades angiogênicas de fatores provenientes do omento. Objetivo - Investigar as alterações nas alturas vilositárias e profundidades de cripta na mucosa intestinal de ratos submetidos a seromiotomia com e sem omentopexia. Métodos - Trinta ratos foram operados após serem divididos em três grupos com 10 animais cada um. No grupo I (GI) os ratos foram submetidos seromiotomia seguida por omentoenteropexia; no grupo II (GII) foi realizada apenas a seromiotomia, e no grupo III (GIII) apenas a laparotomia. Após 60 dias, os animais foram sacrificados e seus intestinos examinados histologicamente, corados pelo tricrômio de Masson, sendo realizado também estudo morfométrico da mucosa intestinal. Resultados - O estudo mostrou que a altura vilositária é maior nos grupos submetidos a seromiotomia, com ou sem omentopexia, do que no grupo em que se realizou laparotomia apenas, porém entre os dois primeiros grupos não houve diferença significante (análise de variância: $P=0,0068$; GI 38,88 $\pm 4,17$; GII $39,41 \pm 6,33$; GIII 31,85 $\pm 5,56$; GI $=$ GII $P>0,05$; GII $>$ GIII $P<0,05$; GI $>$ GIII $P<0,001)$. Conclusões - Não foram demonstradas diferenças quanto às profundidades de criptas entre os grupos $(P=0,60)$. Novos estudos estão sendo realizados por este grupo para acrescentar mais dados sobre o papel da omentopexia como forma de promover neovascularização e crescimento da mucosa intestinal.

DESCRITORES - Omento, cirurgia. Mucosa intestinal. Ratos.

\section{REFERENCES}

1. Cartier R, Brunette I, Hashimoto K, Bourne WM, Schaff HV. Angiogenic factor: a possible mechanism for neovascularization produced by omental pedicles. $\mathrm{J}$ Thorac Cardiovasc Surg. 1990;99:264-8.

2. Goldsmith HS, Griffith AL, Kupferman A, Catsimpoolas N. Lipid angiogenic factor from omentum. JAMA 1984;252:2034-6.

3. Günel E, Tavll L, CaGlayan F, GündoGan AH. Isolated bowel segment created by omentoenteropexy: histologic findings. Pediatr Surg Int. 1997;12(5-6):364-6.

4. Katsikas D, Sechas M, Antypas G, Floudas P, Moshovos K, Gogas J, Rigas A, Papacharalambous N, Skalkeas G. Beneficial effect of omental wrapping of unsafe intestinal anastomoses. Int Surg. 1997;62:435-7.

5. Kimura K, Soper RT. Isolated bowel segment (model 1): creation by mioenteropexy. J Pediatr Surg. 1990;25: 512-3.

6. Kimura K, Soper RT. A new bowel elongation technique for the short-bowel syndrome using the isolated bowel segment lowa models. J Pediatr Surg. 1993;28:792-4.

7. Rocha MM, Martins JL, Patrício F. Histological and immunohistochemical study of a jejunal segment undergoing neovascularization by omentopexy. Transplant Proc. 2002;34:990-2.
8. Rocha MM, Martins JL, Tubino P, Bischoff A. Viability of a jejunal segment after neovascularization by omentoenteropexy. Acta Cir Bras. 2002; $17: 377-80$

9. Rocha MM, Martins JL, Patrício F, Tubino P. Are there any structural alterations in a neovascularized jejunal segment by omentoenteropexy? A histologic and immunohistochemistry study. J Pediatr Surg. 2003;38:1141-6.

10. Ruffini E. Surgical applications of the greater omentum. Panminerva Med. 1992;34:135-40.

11. Shoshany G, Cohen E, Mordohovich D, Hayari L, Har Shai Y, Bar-Maor JA. Creation of the isolated bowel segment in animals by omentoenteropexy. J Pediatr Surg. 1994;29:1344-7.

12. Shoshany G, Diamond E, Mordohovich D, Bar-Maor JA. Jejunal mucosal function of the isolated bowel segment created by omentoenteropexy in dogs: a study by in situ luminal perfusion. J Pediatr Surg. 1995;30:402-5.

Received 2/2/2011 Accepted 3/6/2011 